\title{
Mathematical literacy: A case study on Padang students' mathematical ability
}

\author{
Yulia $^{1}$, Martin Kustati ${ }^{1}$, Juli Afriadi ${ }^{1}$ \\ ${ }^{1}$ UIN Imam Bonjol Padang, Indonesia \\ $\triangle$ yuliampd@uinib.ac.id*
}

\section{Article Information}

Submitted March 09, 2021

Revised April 26, 2021

Accepted April 28, 2021

\section{Keywords}

Mathematical literacy;

Mathematical Ability.

\begin{abstract}
This study aims to analyze student mathematical literacy ability from the perspective of students' Mathematical Ability. This research is a descriptive study with a qualitative approach. The research subjects were three students of XI IPA 1 MAN 1 Padang with different mathematical abilities: low, medium, and high. Data were collected through documentation, tests, and interviews. The results of the analysis show that students with high abilities can solve routine problems, interpret problems and solve them with formulas, carry out procedures well, can deal with complex situations, use their reasoning in solving problems, can work effectively and interpret different representations and then relate them to the real world. Students with moderate abilities can solve routine problems, interpret problems and solve them with formulas, and carry out procedures properly. Meanwhile, students with low abilities are only able to solve routine questions. Based on these results, it is necessary to look for strategies in the mathematics learning process, which enable the improvement of students' mathematical literacy skills.
\end{abstract}

\section{INTRODUCTION}

An increasingly sophisticated era demands educational programs to equip students with the ability to compose, formulate, solve and interpret problems based on real contexts. This ability is called literacy. Literacy is the heart of education (Dinni, 2018). Students with good literacy will find it easy to solve everyday problems (Arding \& Atun, 2020; Kurniawati \& Mahmudi, 2019; Lailiyah, 2017; Nahdi et al., 2020). According to (Kaufman 2013), (Kivunja 2014), Soulé \& Warrick (2015), the success of the literacy of students in schools helps students become individuals who are ready to face the challenges of the 21 st century. Meanwhile, the times have required us to have mathematical abilities and apply mathematical principles in everyday life (Kelly, 2006; Lee \& Ginsburg, 2009). In other words, the proper application of mathematical principles can help solve daily problems.

Mathematical literacy is in line with the goals of mathematics education in Indonesia. (Hayati \& Kamid, 2019; Stacey, 2011; Stacey et al., 2015; Sutisna et al., 2019; Zulkardi et al., 2020). Thus, mathematical literacy is the science of knowing and applying basic mathematics, it is essential to understand the roles and functions of mathematics using reasoning, concepts, facts, mathematical tools, and problem-solving in everyday life. Students' positive perceptions of mathematics lessons and self-confidence in their abilities correlated positively with the mathematics literacy they achieved. Positive perceptions of mathematics can be developed if students are aware of the role of mathematics in life (Kaya \& Aydın, 2016; Mutodi \& Ngirande, 2014).

The studies conducted by (Amir et al., 2019; Aula et al., 2019; Haara et al., 2017; Hairunnisah et al., 2019; Rusdi et al., 2019) mention that students' mathematical literacy skills are still not good. This can be seen from Indonesia's participation in international comparative 
studies, such as PISA (Program for International Student Assessment). As a result, Indonesian contestants in PISA are always in the bottom 10\%, and almost no Indonesian students reach the two highest levels (OECD, 2013; OECD, PISA 2009 Result, 2010; OECD, PISA 2015 Result, 2015; Stacey, 2011). 76\% of Indonesian children in PISA who do not reach level 2, the minimum level is out of the low achievers' category, and the number of children who reach the highest level 5 is only 0.3\% (Nugrahanto \& Zuchdi, 2019; Zulkardi et al., 2020).

The results of the TIMSS study reveal that Indonesian students are still weak in reasoning and problem solving (Fauzan et al., 2018; Rusdi et al., 2019). Low to high ability students are not familiar with questions that require logical thinking and applied solutions (Boesen et al., 2010; Psycharis \& Kallia, 2017). Students can only understand concepts but are unable to connect between concepts and are unable to apply them. It was caused by a lack of student interest and motivation towards mathematics (Fauzan et al., 2013). The other experts found that mathematics learning in schools, in general, is not in line with (Nugrahanto \& Zuchdi, 2019; Stacey, 2011), mechanistic (Acharya, 2017; Fauzan et al., 2013), is still generally dominated by teachers, students passively accept what the teacher gives, and it is still in the form of one-way interaction (Otoo et al., 2018).

Based on the results of observations and interviews conducted on November 16, 2020, at Islamic secondary school 1 in Padang has implemented literacy. However, students have not been described as tests that can measure students' mathematical literacy skills. Students' literacy skills cannot be measured only by typical questions given by the teacher. Students' mathematical literacy abilities can be measured from the results of the PISA test questions. In addition, this study also found differences in students' mathematical abilities. This certainly affects students' literacy skills.

With mathematical literacy skills, students can improve students' mathematical ability in mathematics, i.e., understanding and making decisions. This is in line with the opinion of (Aizikovitsh-Udi \& Cheng, 2015; Chukwuyenum, 2013; Widana et al., 2018; Yasin et al., 2019) opinion, which states that with the ability to think critically in mathematics, students will be able to use these abilities in daily life. Students who have mathematical abilities will be calm in dealing with problems. By understanding the problem, students can know the cause of the problem and the right solution to solve the problem. Then, they will make the right decision. If these students are accustomed to critical mathematical thinking, students will not depend on others. These students will form an independent character. By thinking critically, an independent character will foster an attitude of nationalism so that it is not easily provoked by issues that are appearing in society at this time (Yasin et al., 2019).

Efriani \& Putri (2019), Firdaus (2017), and Hadi et al. (2018), found that the mathematics literacy of the high school students in her study sample was still low even though the questions had been adjusted to the Indonesian context. The students answered the choice of answers to the mathematics questions without explanation and the calculation steps. This shows that students cannot provide descriptions or arguments to the math problems tested in the math test (Habsah, 2017; Saleh et al., 2018; Widyatiningtyas et al., 2015). According to (Amir et al., 2019; Aula et al., 2019), the profile of mathematical literacy abilities are divided into six levels, students with low mathematical abilities are only able to reach level 1, moderate students can answer questions with a familiar and known context, and all relevant information is available with straightforward questions. Students with high abilities can identify information and solve problems (Efriani \& Putri, 2019). The level of 
mathematical literacy skills is due to the material, learning provided by the teacher, the class and family environment, the student's abilities, and readiness in implementing learning (Amir et al., 2019; Haara et al., 2017).

Several other previous studies state that to determine students' critical thinking in learning mathematics, the teachers need to design materials, stimulating the students' higherorder thinking skills to discover their learning and answer the questions (Ugwuozor et al., 2020). Thus, it is not easy because the teachers should use appropriate strategies to design their questions. After the questions and materials are presented, they are expected to assist their students, too (Janssen et al., 2019; Janssen et al., 2019). In other words, the teachers teach mathematics to their students to achieve critical thinking skills well. However, some teachers sometimes do not fully pay attention to this goal of learning. Ideally, the teachers should get deep concepts, because he or she can transfer knowledge if he or she already understands the concept well (Kezer \& Turker, 2012).

Based on the preliminary study, when the teachers are given non-routine questions, some cannot answer them well. Many studies have identified the importance of critical thinking in learning geometry (Yi et al., 2020). Then, (Aizikovitsh-Udi \& Cheng 2015) have examined how teachers develop mathematical problems by measuring critical thinking. Then, (Nuraisah et al. 2016) have also examined how to identify critical thinking on fraction materials.

There is no specific research focusing on mathematical literacy skills on the topics of circles, number patterns, graphics, and spacious building. Thus, it is essential to research the mathematical literacy abilities of students in this school in solving problems adapted from PISA, which previously were rarely given to MAN students. 1 Padang, besides that, this research also aims to make students more familiar with PISA questions so that students' mathematical abilities will be more developed than before, who only solve ordinary problems. The PISA questions used in this every accommodate all levels of ability measured in PISA. This research was conducted to determine the students' mathematical literacy abilities according to the ability levels determined by PISA. The difference between this research and previous research is that students' mathematical literacy skills are measured using mathematical ability questions at the PISA level, especially on Circles, Numbers, Patterns, Function Graphs, and Spatial constructs.

\section{METHODS}

This research is descriptive research with a qualitative approach. According to (Kelley et al., 2003; Miles et al., 2014; Zimmerman, 2001), descriptive research is research conducted to describe or explain systematically, factually, and accurately the nature of a particular population. (Miles et al., 2014) suggest that a qualitative approach intends to understand the phenomena experienced by research subjects such as behavior, perceptions, motivation, and actions holistically and descriptively in the form of words and language in a context. Unique nature and by making use of various natural methods.

The subjects of this research are the XI IPA students of MAN 1 Padang. The sampling method in this study is purposive sampling, which described the mathematical literacy abilities of students in solving literacy test questions and on the results of interviews. The classification of students' mathematical ability is based on the first semester of mathematics test scores. The researchers asked the teacher regarding students' ability level. The research 
subjects were three students at different levels of mathematical ability. Mathematical abilities are grouped according to the average math scores on odd semester examinations according to the score categories in Table 1.

Table 1. Initial Mathematics ability category (Indrawati et al., 2019)

\begin{tabular}{lll}
\hline No. & Score & Category \\
\hline 1 & Score $\leq 80$ & Low \\
2 & $80<$ Score $<85$ & Moderate \\
3 & Score $\geq 85$ & High \\
\hline
\end{tabular}

Data collection methods in this research are test and interview methods. Interviews were conducted to determine the achievement of students' mathematical literacy level indicators that were not visible on the test results. In this study, the analysis carried out was the analysis of student indicator achievement at each level of mathematical literacy skills. Indicators of the level of mathematical literacy skills used are shown in Table 2

Table 2. Indicators of Mathematical Literacy Ability in PISA

\begin{tabular}{ll}
\hline Level & \multicolumn{1}{c}{ Indicators } \\
\hline 1. & Students can answer questions in a known context since all information is available, \\
identify information and carry out general ways based on clear instructions and show \\
action following the stimulation given. \\
Students interpretation and recognize stimulation with contexts that require direct \\
conclusions, sort relevant information from a single source, and use a single presentation \\
method and work on basic algorithms, use formulas, carry out procedures or agreements \\
Students apply procedures or decisions sequentially, solve problems, implement simple \\
strategies, interpret and use representations based on different sources of information, state \\
the reasons directly, and communicate the results of their interpretations and reasons \\
Students work effectively with models in concrete but complex situations, which may \\
involve making assumptions, selecting and combining different representations, including \\
symbols, relating them to real situations, using their limited range of skills, and arguing \\
with multiple contextual views. Clear and provide explanations and communicate them \\
accompanied by arguments based on their interpretations and actions. \\
Students develop and work with models for complex situations, identify problems, and set \\
assumptions, select, compare, and evaluate appropriate problem-solving strategies related \\
to complex problems related to models, work strategically by using broad thinking and \\
reasoning, and appropriately relate symbolic representations and formal characteristics and \\
knowledge related to situations and reflect on their work and be able to formulate and \\
communicate their interpretations and reasons \\
Students conceptualize, generalize and use information based on study and modeling in a \\
complex situation and can use above-average knowledge, connect different information \\
sources and presentations, and translate between them flexibly, apply knowledge, mastery, \\
and the relationship of symbols and mathematical operations, developing new strategies \\
and approaches for dealing with new situations, as well as reflecting on their actions and \\
formulating and communicating their actions appropriately and describing concerning their \\
findings, interpretations, opinions, and suitability to real situations.
\end{tabular}

Source: PISA (OECD, 2014:61)

The triangulation technique used in this study was investigator triangulation. Triangulation is carried out by providing investigator analysis sheets, subject answer sheets, and recorded interviews. The results of the researcher's analysis are then compared with the results of the investigator's analysis. If there are differences, a discussion will be held with the investigator concerned to obtain the same view. The final stage is to determine the level of mathematical literacy skills achieved by each subject. 


\section{RESULTS AND DISCUSSION}

This research was started by asking for data on students' odd semester test scores from the subject teachers in class XI IPA 1. Based on these data, it is known that $30 \%$ of students with low math abilities, $50 \%$ of students with moderate abilities, and $20 \%$ high. Furthermore, by asking the teacher's opinion, the research subject is determined. There were three research subjects with different mathematical abilities with the $S 1$ code for low-ability subjects with the initials NS, S2 for medium-capable subjects with the initials AZF, and S3 for high-ability subjects with the initials FDS.

\section{The student with Low Mathematical Ability (S1)}

Based on the analysis results, the student with low math abilities (S1) was able to work on three questions. S1 can correctly answer questions that can measure level 1 mathematical literacy skills. In addition, S1 can answer questions in a familiar context and all relevant information available with precise questions. This is based on the S1's answer in Figure 1.

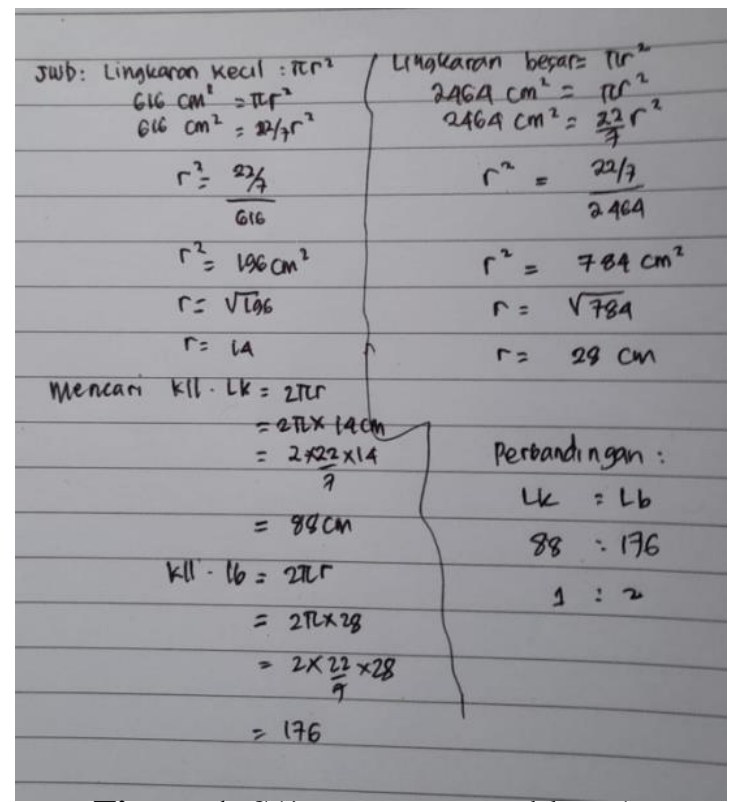

Figure 1. S1's answer to problem la

S1 can identify information and perform general methods based on clear instructions; this can be seen in the $\mathrm{S} 1$ identification results in question 1a, shown in Figure 2.

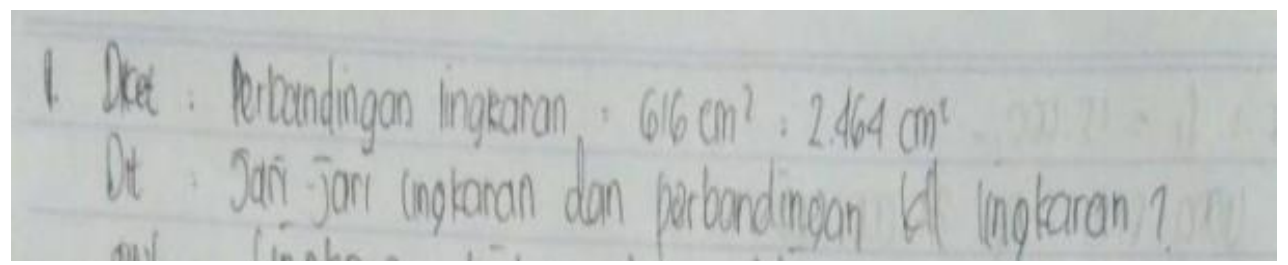

Figure 2. S1 Identification of problem 1a

S1 can show an action according to a given stimulus. This can be seen in the results of interviews with S1. S1 can answer questions correctly, questions that can measure the level. Two mathematical literacy skills. Based on the results of answers and interviews, S1 has met all indicators at level 2. S1 can interpret and recognize situations with contexts that require 
direct conclusions. This can be seen in the results of $\mathrm{S} 1$ identification in question $1 \mathrm{~b}$ in Figure 3.

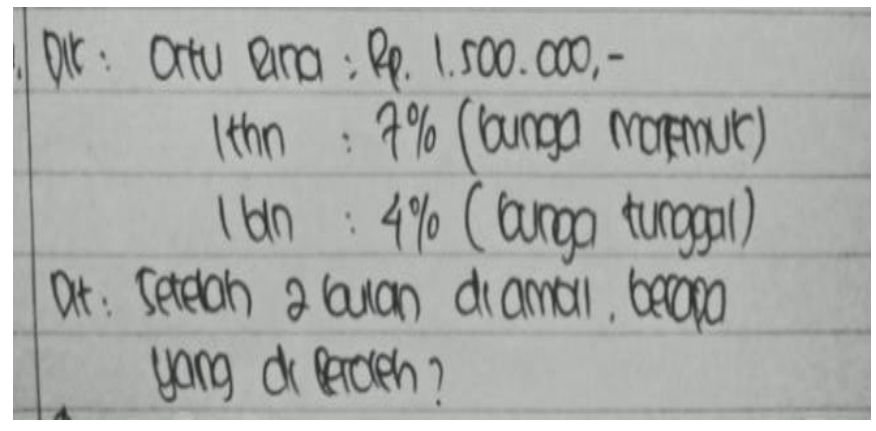

Figure 3. S1 Identification of problem $1 \mathrm{~b}$

S1 can select relevant information from much information provided; this can be seen in interviews with S1. S1 chooses single interest to answer question 1b. S1 understanding of social arithmetic is excellent, proven during the interview, namely how to do question $1 \mathrm{~b}$. S1 explains it in detail and correctly. S1 can provide good direct reasons for the answers to the questions he wrote.

In questions that can measure mathematical literacy level 3, S1 only writes what he knows. When the researcher fished for an answer from S1, S1 said that he did not know. S1 is still confused about answering questions that can measure level 3 mathematical literacy skills. This can be seen in the results of S1 answers and the results of interviews with S1. Based on this, $\mathrm{S} 1$ does not fulfill all indicators at level 3.

$\mathrm{S} 1$ does not answer questions that can measure level 3 mathematical literacy skills. When the researcher conducted the interview, S1 said that he did not know. S1 also does not meet the indicators at level 5 and level 6 . Based on this, S1 only meets the indicators up to level 2. This is following the results of the analysis conducted by investigators so that $\mathrm{S} 1$ is at level 2 of mathematical literacy.

\section{The student with moderate Mathematical Ability (S2)}

Based on the analysis results, students with moderate mathematical ability (S2) can work on questions up to questions that can measure level 3 mathematical literacy skills. S2 can answer questions that can measure mathematical literacy skills at level 1 correctly. Based on the results of S2's answer to question number $1 \mathrm{~b}, \mathrm{~S} 2$ can answer questions in a familiar context, and all relevant information is available. S2 can identify information and perform general methods based on explicit instructions. Based on the results of interviews with S2, S2 was able to show action following the stimulus given. Therefore S2 fulfills all indicators in level 1 .

S2 can answer correctly questions that can measure level 2 mathematical literacy skills. Based on the results of answers and interviews, S2 has met all indicators at level 2. S2 can interpret and recognize situations with contexts that require direct conclusions. This is shown in Figure 4. 


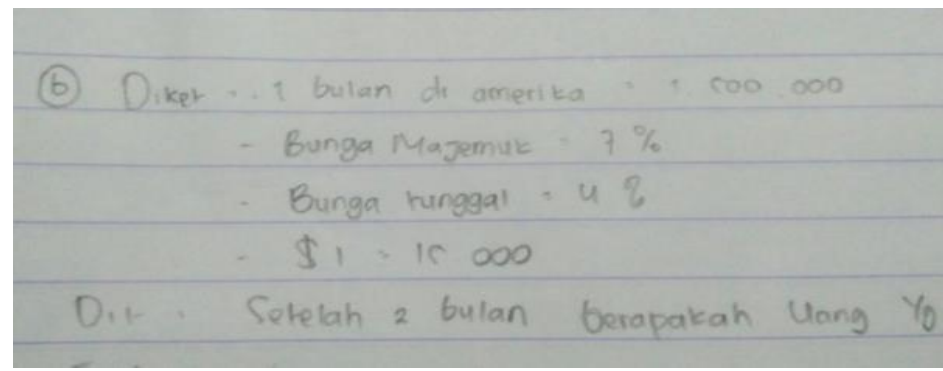

Figure 4. S2 Identification of Problem 1b

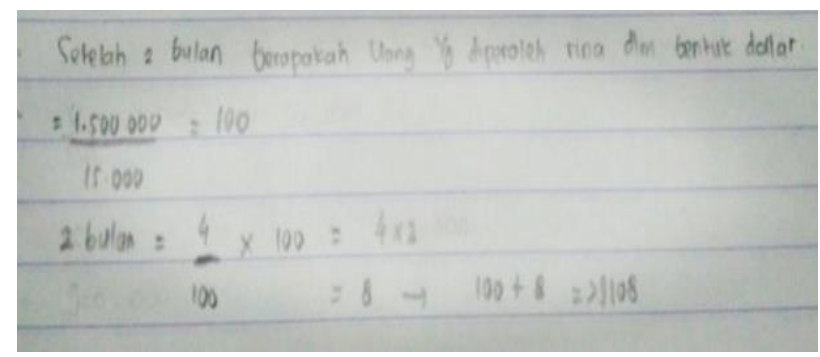

Figure 5. S2's answer to Problem $1 b$

Based on interviews with S2, S2 selected relevant information from a single source and used a single assessment. S2 can use social arithmetic formulas well. This is shown in Figure 5.

S2 can provide reasons directly and make an actual interpretation in answering question 1b. This can be seen in the results of the interview with S2. Meanwhile, S2 can correctly answer questions that can measure level 3 mathematical literacy skills. Based on the results of answers and interviews, S2 has met all the indicators at level 3. So that S2 meets level 3 in questions that can measure mathematical literacy level 4. S2 cannot answer the questions correctly. S2 chose Figure A while the correct answer is Figure B. Figure B is the correct image for the velocity graph in question 4 . When interviewed why S2 chose Figure A. S2 said that he was only guessing the answer. Based on the interview results, it can be concluded that S2 has not been able to work effectively using models. S2 also has not been able to connect the graph with the shape of the path that has been taken. S2 also has not been able to provide a strong reason because S2 only estimates. Based on the results of interviews and answers written by $S 2$, the $S 2$ could not meet the indicators for level 4. S2 also did not meet the indicators at levels 5 and 6 because $\mathrm{S} 2$ could not solve the problem or find a strategy to solve it. Based on this explanation, S2 is at level 4.

\section{The student with High Mathematical Ability (S3)}

Based on the students' answers with the high mathematical ability (S3), they can work on five questions. S3 can answer questions that can measure level 1 mathematical literacy skills correctly. S3 can meet all indicators of mathematical literacy level 1. S3 can answer questions in a familiar context, and all relevant information is available with clear questions. S3 can identify information and perform standard methods based on clear instructions. S3 is also able to show an action according to a given stimulus.

S3 can answer questions that can measure level 2 mathematical literacy skills correctly. The results of tests and interviews show that S3 meets all indicators at level 2. S3 can interpret and recognize situations with contexts that require direct conclusions. This is based on Figure 6. 


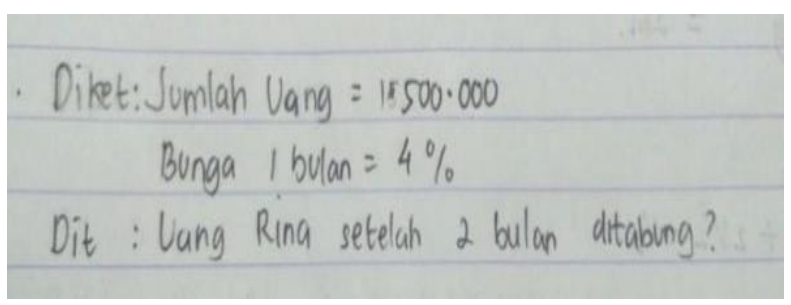

Figure 6. S3 Identification in Problem 1b

S3 can sort the relevant information from a single source and use a single presentation method. Understanding the use of S3 social arithmetic formulas is also good; it can be seen in Figure 7. S3 can provide direct reasons and carry out the actual interpretation.

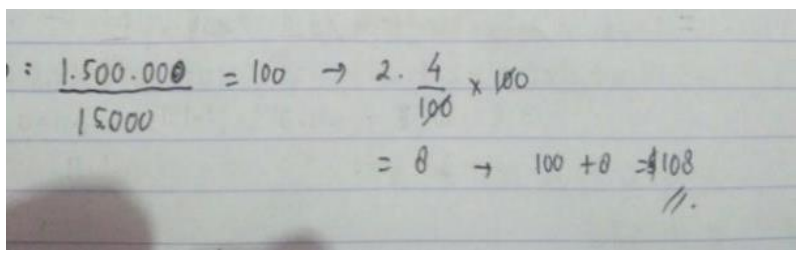

Figure 7. S3's Answer to Problem $1 b$

S3 can answer questions that can measure level 3 mathematical literacy skills correctly and meet all level 3. S3 can carry out procedures clearly, including procedures that require sequential decisions. S3 can solve problems and implement simple strategies. S3 can interpret and use representations based on different sources of information and state the reasons directly based on interviews. S3 can communicate the results of their interpretations and reasons.

In questions that can measure mathematical literacy level 4, S3 can solve the problems correctly. S3 has been able to meet all indicators at level 4 of mathematical literacy ability. Likewise, with the questions to measure mathematical literacy skills at level 5, S3 can also meet all indicators well. This has been explained in the results above. So it can be said that S3 has reached level 5 in mathematical literacy skills. In question number $4 \mathrm{~b}$, which measures the mathematical literacy skills of high-ability students (S3), S3 has not been able to work on the questions. When being interviewed about why they did not solve the questions, S3 said that due to the lack of information provided by the questions, they could not solve the problems in the questions or find a strategy to solve them. Based on the results of interviews and answers written by S3, S3 has not met the level 6 indicators.

The student with high mathematical ability in recognizing the problem understands and represents the ideas being asked in the questions precisely and accurately. This is following the opinion of (Aula et al., 2019; Hairunnisah et al., 2019; Sutisna et al., 2019), which states that those who are not procedural are more adept at obtaining a clear form of the situation at hand with just one sentence.

The student with moderate ability in recognizing the problem mentions what is known and what is asked of the questions precisely and accurately. Subjects in this category can make descriptions, mathematical design models and arrange them. Students in the low ability category in recognizing the dominant idea of the problem at hand, the subject is still confused in understanding the problem, unable to recognize the dominant idea of the problem well. The subject is often incomplete to write and explain the main problem of the problem at hand. This is following the opinion of (Hairunnisah et al. 2019), which states that the dominant idea does not lie in the situation but lies in someone's observation. 


\section{CONCLUSIONS}

Based on the results of tests and interviews and analysis, it can be concluded that students with high abilities can solve routine problems, interpret problems and solve them with formulas, carry out procedures well, can deal with complex situations, use their reasoning in solving problems, can work effectively and interpret different representations and then relate them to the real world. Students with moderate abilities can solve routine problems, interpret problems and solve them with formulas, and carry out procedures properly. Meanwhile, students with low abilities are only able to solve routine questions.

It is recommended that further researchers conduct similar or more in-depth research considering the importance of students' mathematical literacy abilities from other perspectives material. Future researchers are expected to expand the research sample. Furthermore, they can also develop this research into further research, e.g., thinking skills and gender.

\section{AUTHOR CONTRIBUTIONS STATEMENT}

YY worked as the main drafter in this research. Data collection and instrument design assisted by MK and JA.

\section{REFERENCES}

Acharya, B. R. (2017). Factors affecting difficulties in learning mathematics by mathematics learners. International Journal of Elementary Education, 6(2), 8-15.

Aizikovitsh-Udi, E., \& Cheng, D. (2015). Developing mathematical ability from dispositions to abilities: Mathematics education from early childhood to high school. Creative Education, 6(04), 455.

Amir, M. F., Mufarikhah, I. A., Wahyuni, A., Nasrun, N., \& Rudyanto, H. E. (2019). Developing 'fort defending'game as a learning design for mathematical literacy integrated to primary school curriculum in Indonesia. Elementary Education Online, $18(3)$.

Arding, N. I., \& Atun, S. (2020). Analysis of junior high school students' scientific literacy on simple effort and aircraft for everyday life. Journal of Physics: Conference Series, $1440(1), 012095$.

Aula, M. F. R., Suyitno, H., \& Rosyida, I. (2019). Mathematical literacy ability viewed from student's learning style based on gender differences on PBL assistance project assessment. Unnes Journal of Mathematics Education Research, 8(1), 96-103.

Boesen, J., Lithner, J., \& Palm, T. (2010). The relation between types of assessment tasks and the mathematical reasoning students use. Educational Studies in Mathematics, $75(1), 89-105$.

Chukwuyenum, A. N. (2013). Impact of critical thinking on performance in mathematics among senior secondary school students in Lagos State. IOSR Journal of Research \& Method in Education, 3(5), 18-25.

Dinni, H. N. (2018). HOTS (High Order Thinking Skills) dan kaitannya dengan kemampuan literasi matematika. PRISMA, Prosiding Seminar Nasional Matematika, 1, 170-176.

Efriani, A., \& Putri, R. I. I. (2019). Sailing Context in PISA-Like Mathematics Problems. Journal on Mathematics Education, 10(2), 265-276.

Fauzan, A., Musdi, E., \& Afriadi, J. (2018). Developing learning trajectory for teaching statistics at junior high school using RME approach. Journal of Physics: Conference Series, 1088(1), 012040. 
Fauzan, Ahmad, Plomp, T., \& Gravemeijer, K. (2013). The development of an rme-based geometry course for Indonesian primary schools. Educational Design Research-Part B: Illustrative Cases, 159-178.

Firdaus, F. M. (2017). Improving primary students' mathematical literacy through problem based learning and direct instruction. Educational Research and Reviews, 12(4), 212 219.

Haara, F. O., Bolstad, O. H., \& Jenssen, E. S. (2017). Research on mathematical literacy in schools-aim, approach and attention. European Journal of Science and Mathematics Education, 5(3), 285-313.

Habsah, F. (2017). Developing teaching material based on realistic mathematics andoriented to the mathematical reasoning and mathematical communication. Jurnal Riset Pendidikan Matematika, 4(1), 43-55.

Hadi, S., Retnawati, H., Munadi, S., Apino, E., \& Wulandari, N. F. (2018). The difficulties of high school students in solving higher-order thinking skills problems. Problems of Education in the 21 st century, 76(4), 520.

Hairunnisah, H., Suyitno, H., \& Hidayah, I. (2019). Students mathematical literacy ability judging from the adversity quotient and gender in problem based learning assisted edmodo. Unnes Journal of Mathematics Education Research, 8(2), 180-187.

Hayati, T. R., \& Kamid, K. (2019). Analysis of mathematical literacy processes in high school students. International Journal of Trends in Mathematics Education Research, 2(3), 116-119.

Indrawati, K. A. D., Muzaki, A., \& Febrilia, B. R. A. (2019). Profil berpikir siswa dalam menyelesaikan soal sistem persamaan linear. Jurnal Didaktik Matematika, 6(1), 6883.

Janssen, E. M., Mainhard, T., Buisman, R. S., Verkoeijen, P. P., Heijltjes, A. E., van Peppen, L. M., \& van Gog, T. (2019). Training higher education teachers' critical thinking and attitudes towards teaching it. Contemporary Educational Psychology, 58, $310-322$.

Janssen, E. M., Meulendijks, W., Mainhard, T., Verkoeijen, P. P., Heijltjes, A. E., van Peppen, L. M., \& van Gog, T. (2019). Identifying characteristics associated with higher education teachers' Cognitive Reflection Test performance and their attitudes towards teaching critical thinking. Teaching and Teacher Education, 84, 139-149.

Kaufman, K. J. (2013). 21 ways to 21st century skills: Why students need them and ideas for practical implementation. Kappa Delta Pi Record, 49(2), 78-83.

Kaya, D., \& Aydın, H. (2016). Elementary mathematics teachers' perceptions and lived experiences on mathematical communication. Eurasia Journal of Mathematics, Science and Technology Education, 12(6), 1619-1629.

Kelley, K., Clark, B., Brown, V., \& Sitzia, J. (2003). Good practice in the conduct and reporting of survey research. International Journal for Quality in Health Care, 15(3), 261-266.

Kelly, C. A. (2006). Using manipulatives in mathematical problem solving: A performancebased analysis. The Mathematics Enthusiast, 3(2), 184-193.

Kezer, F., \& Turker, B. (2012). Comparison of the critical thinking dispositions of (studying in the secondary science and mathematics division) preservice teachers. ProcediaSocial and Behavioral Sciences, 46, 1279-1283. 
Kivunja, C. (2014). Do you want your students to be job-ready with 21 st century skills? Change pedagogies: A pedagogical paradigm shift from vygotskyian social constructivism to critical thinking, problem solving and siemens' digital connectivism. International Journal of Higher Education, 3(3), 81-91.

Kurniawati, N. D. L., \& Mahmudi, A. (2019). Analysis of mathematical literacy skills and mathematics self-efficacy of junior high school students. Journal of Physics: Conference Series, 1320(1), 012053.

Lailiyah, S. (2017). Mathematical literacy skills of students' in term of gender differences. AIP Conference Proceedings, 1868(1), 050019.

Lee, J. S., \& Ginsburg, H. P. (2009). Early childhood teachers' misconceptions about mathematics education for young children in the United States. Australasian Journal of Early Childhood, 34(4), 37-45.

Miles, M. B., Huberman, A. M., \& Saldana, J. (2014). Qualitative data analysis: A methods sourcebook.

Mutodi, P., \& Ngirande, H. (2014). The influence of studentsperceptions on Mathematics performance. A case of a selected high school in South Africa. Mediterranean Journal of Social Sciences, 5(3), 431.

Nahdi, D. S., Jatisunda, M. G., Cahyaningsih, U., \& Suciawati, V. (2020). Pre-service teacher's ability in solving mathematics problem viewed from numeracy literacy skills. Elementary Education Online, 19(4), 1902-1910.

Nugrahanto, S., \& Zuchdi, D. (2019). indonesia pisa result and impact on the reading learning program in Indonesia. International Conference on Interdisciplinary Language, Literature and Education (ICILLE 2018), 373-377.

Nuraisah, E., Irawati, R., \& Hanifah, N. (2016). Perbedaan pengaruh penggunaan pembelajaran konvensional dan pendekatan kontekstual terhadap kemampuan berpikir kritis matematis dan motivasi belajar siswa pada materi pecahan. Jurnal Pena Ilmiah, 1(1), 291-300.

Otoo, D., Iddrisu, W. A., Kessie, J. A., \& Larbi, E. (2018). Structural model of students' interest and self-motivation to learning mathematics. Education Research International, 2018.

Psycharis, S., \& Kallia, M. (2017). The effects of computer programming on high school students' reasoning skills and mathematical self-efficacy and problem solving. Instructional Science, 45(5), 583-602.

Rusdi, R., Fauzan, A., Arnawa, I. M., \& Lufri, L. (2019). development of mathematics teaching materials based on realistic mathematics education and literacy in junior high school. 1st International Conference on Innovation in Education (ICoIE 2018), 120 125.

Saleh, M., Prahmana, R. C. I., \& Isa, M. (2018). Improving the reasoning ability of elementary school student through the Indonesian realistic mathematics education. Journal on Mathematics Education, 9(1), 41-54.

Soulé, H., \& Warrick, T. (2015). Defining 21st century readiness for all students: What we know and how to get there. Psychology of Aesthetics, Creativity, and the Arts, 9(2), 178.

Stacey, K. (2011). The PISA view of mathematical literacy in Indonesia. Indonesian Mathematical Society Journal on Mathematics Education, 2(2), 95-126. 
Stacey, K., Almuna, F., Caraballo, R. M., Chesné, J.-F., Garfunkel, S., Gooya, Z., Kaur, B., Lindenskov, L., Lupiáñez, J. L., \& Park, K. M. (2015). PISA's influence on thought and action in mathematics education. In Assessing Mathematical Literacy (pp. 275306). Springer.

Sutisna, A. P., Budi, A. S., \& Noornia, A. (2019). The influence of the realistic mathematics education approach and early mathematical ability to mathematical literacy. Int. J. Multidiscip. Curr. Res, 6, 798-801.

Ugwuozor, F. O., Ede, M. O., Ifelunni, O. C., \& Abiogu, G. C. (2020). Teachers' demographic variables as predictors of mathematical ability of school children: Implications for school counselling. Glob J Health Sci, 12, 91-101.

Widana, I. W., Parwata, I., Parmithi, N. N., Jayantika, I., Sukendra, I. K., \& Sumandya, I. W. (2018). Higher order thinking skills assessment towards critical thinking on mathematics lesson. International Journal of Social Sciences and Humanities, 2(1), $24-32$.

Widyatiningtyas, R., Kusumah, Y. S., Sumarmo, U., \& Sabandar, J. (2015). the impact of problem-based learning approach to senior high school students' mathematics critical thinking ability. Indonesian Mathematical Society Journal on Mathematics Education, 6(2), 30-38.

Yasin, M., Jauhariyah, D., Madiyo, M., Rahmawati, R., Farid, F., Irwandani, İ., \& Mardana, F. F. (2019). The guided inquiry to improve students mathematical mathematical ability using student's worksheet. Journal for the Education of Gifted Young Scientists, 7(4), 1345-1360.

Yi, M., Flores, R., \& Wang, J. (2020). Examining the influence of van Hiele theory-based instructional activities on elementary preservice teachers' geometry knowledge for teaching 2-D shapes. Teaching and Teacher Education, 91, 103038.

Zimmerman, J. L. (2001). Conjectures regarding empirical managerial accounting research. Journal of Accounting and Economics, 32(1-3), 411-427.

Zulkardi, Z., Putri, R. I. I., \& Wijaya, A. (2020). Two decades of realistic mathematics education in Indonesia. In International reflections on the Netherlands didactics of mathematics (pp. 325-340). Springer, Cham. 